\title{
Chapter 12 \\ Teachers' Classroom Engagement Structures: A Comparative Study of a Novice US and an Experienced UK Mathematics Teacher
}

\author{
Deena Khalil, Elizabeth Lake and Ayanna Johnson
}

\begin{abstract}
This chapter describes the 'in-the-moment' affect of one novice and one experienced teacher by building on the contributions of Goldin, Epstein, Schorr, and Warner's (2011) 'engagement structure' archetypes. The two case studies depict the powerful mathematical affect exhibited whilst teaching by describing a constellation of interacting strands within each structure. Findings reveal that engagement structures, first theorised for students, may be inferred from observations across different demographic and professional teaching contexts. We believe the value of engagement structures is in helping teachers notice how their 'in-the-moment' behaviour as mathematics teachers may mirror the 'in-the-moment' behaviour of their mathematics learners. We suggest engagement structures offer a lens for examining teachers' affective states, and the role the affective domain can play in teacher education and professional development.
\end{abstract}

Keywords Emotions • Engagement structures • "In-the-moment" affect • Mathematics teaching $\cdot$ Teacher professional development

\subsection{Introduction}

Policymakers, politicians, and practitioners agree that one of the most important inschool relationships students have access to are teachers, and research supports this notion (Hill \& Ball, 2009; Planke \& Condliffe, 2013). The issue of teacher recruitment and retention, and the myriad of factors affecting teachers', $\mathrm{p}$ job dissatisfaction then, is important (Au, 2007; Collie, Shapka, \& Perry, 2012; Haberman, 2005).

D. Khalil $(\bowtie) \cdot$ A. Johnson

Howard University, 2400 Sixth St. NW, Washington, DC 20059, USA

e-mail: deena.khalil@howard.edu

E. Lake

Institute of Education, University College London, 20 Bedford Way, Bloomsbury, London,

WC1H 0AL, UK

e-mail: elizabeth.lake@ucl.ac.uk

University of East Anglia, Norwich Research Park, Norwich, NR4 7TJ, UK

(C) The Author(s) 2019

M. S. Hannula et al. (eds.), Affect and Mathematics Education,

ICME-13 Monographs, https://doi.org/10.1007/978-3-030-13761-8_12 
Mathematics teachers are no exception, with many leaving teaching within their first few years (Ingersoll \& Perda, 2010; Liu, Rosenstein, Swan, \& Khalil, 2008). One reason for teacher attrition is teacher burnout and stress (e.g. Kyriacou, 2001), where such conditions are linked to negative teacher affect (e.g. stress, low self-efficacy) and engagement with their environment. Scholars have argued that an individual's affective well-being in organisations can lessen burnout and job dissatisfaction whilst improving engagement and retention (Carmack, 2014), particularly among teachers (Parker, Martin, Colmar, \& Liem, 2012).

Therefore, an area worth considering is teachers' affect (Gee, 2002; Goldin, 2014; Moore, 2008); particularly among mathematics teachers. Some scholars have described how mathematics teachers may experience more and comparatively stronger emotions (e.g. mathematics anxiety, low self-efficacy) compared to other teachers (Bursal \& Paznokas, 2006; Goldin, 2014). Others, like Liljedahl (2005), suggest that teachers who are more attentive to their affective domains also experience change in their attitude and beliefs towards mathematics topics, possibly resulting in higher confidence in their mathematical ability. This mimics a similar finding reported by DeBellis and Goldin (2006) when they examined, by observing students, behaviours and emotional expressions during various mathematical tasks. They suggest that participants who could recognize their affect, and who could develop metaaffect within themselves, were able to unlock confidence in their mathematical ability. If within mathematics education our agenda is to describe the essential components of powerful affect within learning environments, where powerful implies a productive and potentially more adaptive outcome (Goldin, 2014), then examining teacher inthe-moment emotions in relation to mathematics classroom experiences is essential; such examination may identify where affect has the potential to be used to develop meta-affective traits in teachers, which in turn may have an indirect positive influence on students' in-the-moment emotions and confidence as well.

One possible way to infer teachers' 'in-the-moment' affect is through observations of teachers practicing in both controlled clinical experiences in teacher preparation programmes (Dieker, Hynes, Hughes, \& Smith, 2008) and within the chaotic dynamics of everyday classrooms (Meyer \& Turner, 2006; Schorr \& Goldin, 2008). Though the observation of mathematics as an emotionally challenging endeavour is well established, Bibby (2002) noted that the exploration into the connection between emotion and learning is much more recent. Some of the most recent research comes from other disciplines. For example, there is growing recognition within neuroscience of the importance of emotion within corporal responses to cognitive processing. Emotions acts as a trigger for and driver of cognitive development (Brown \& Reid, 2006; Dalgleish \& Power, 1999; Damasio, 2006; Drodge \& Reid, 2000). Other recent research recognises that difficulties in learning mathematics in context have more complex roots than simply addressing teaching as activating cognitive procedures or learning concepts (Calvo \& D'Mello, 2011). For example, Titsworth, McKenna, Mazer, and Quinlan (2013) talk about exposure to positive emotions as better for supporting recall, whilst Mottet and Beebe (2002) suggest that affect directly determines time spent on a task. 
While we know that teachers can inspire and motivate students to engage with mathematics (Zeldin \& Pajares, 2000), what is not yet sufficiently researched is how such emotions as experienced by teachers may influece their behaviours when engaging with students during daily interaction. Whilst there are numerous quantitative studies that document factors that influence teachers' affective traits (e.g. self-efficacy studies), few studies examine them qualitatively (Goldin, 2014). Fewer still examine "in-the-moment" affective states, and possible links between affective states and their relationship with the praxes of teaching (Hagenauer, Hascher, \& Volet, 2015; Khalil, Hughes, Gosselin, \& Edwards, 2016). One of the reasons why emotion as a state is rarely examined is the complexity of inferring them during a teaching context. More specifically, the issue of the hidden nature of emotions makes research highly interpretive. Fenton-O'Creevy, Soane, Nicholson, and Willman (2011) posited that "applied empirical work in field settings [on emotion] has been limited" (p. 1045), because researchers attempting to tackle the issue found it difficult logistically, as the fluidity of communication between teacher and student has multiple agendas and levels.

In this paper, we propose using engagement structures (ES) to explore teachers' emotions whilst in action (Goldin et al., 2011). First inferred from observing students solve algebraic and calculus mathematical problems using SimCalc software, the construct of ES is intended to provide a comprehensive tool by which to examine the affective dimension of learning (Schorr \& Goldin, 2008; Schorr, Epstein, Warner $\&$ Arias, 2010). In this paper, we use this model of ES to describe the affective dimension of teaching. In the following paragraphs, we describe the ES that were inferred from the teaching practices of two mathematics teachers: Mykia, a novice teacher, who 'rehearses' an upper elementary school mathematics lesson twice as part of her lesson study, and Adam, an experienced high school teacher in the UK. These are the first and second cases respectively.

We sought to use the differing cases of Mykia and Adam because we wanted to propose that, despite the dissimilarity in contextual factors and temporal levels of teacher education experience (elementary vs. secondary, United States vs. United Kingdom, urban vs. rural, novice vs. experienced, Black female vs. white male), engagement structure archetypes may indeed be inferred from the act of teaching as well as learning mathematics regardless of such differences. As critical instance case studies, the examples of Mykia and Adam allow for thorough investigation of specific instances of a phenomenon and can provide answers to questions raised about possible assertions through detailed study (Gerring, 2017). Thus, we chose these critical instances that investigated the teaching differences between Mykia and Adam to "[in]form an essential part of a teacher's identity in terms of ... personal development" (Goldin, Rösken, \& Törner, 2009), informing us of the possible ways teachers' affective positioning can influence sociomathematical norms and practices. Mykia exemplifies a teacher candidate whose affect alters her practices noticeably over time, whilst Adam represents how such changes in affect may become less noticable once elements of classroom practice are experienced. We precede these cases with a literature review to further juxtapose the similarities and differences of 
the two cases, in an attempt to provoke discussion about the in-the-moment affect of the two teachers as they teach mathematics lessons.

\subsection{Perspective and Conceptual Framework}

This enquiry is grounded in two bodies of literature, the first on the theory of ES that relates the role mathematical affect has on one's 'doing' mathematics as a learner (Goldin, 2014; McLeod, 1994). The second is on the professional dimensions of teacher's learning trajectory and practice (Borko, 2004).

First, we build on Goldin and colleagues' work (Goldin, 1998, 2000; Goldin, Epstein, and Schorr, 2007; Schorr \& Goldin, 2008; Schorr et al., 2010) that led to their theory of ES. An ES is characterised as a "behavioural/affective/social constellation," that situates and describes "in-the-moment" states that individuals experience when interacting with mathematics as problem solving (Goldin et al., 2011, p. 549). The original nine ES are archetypes, identified as Get the Job Done, Look How Smart I Am, Check This Out, I'm Really Into This, Don't Disrespect Me, Stay Out Of Trouble, It's Not Fair, and Let Me Teach You. Each ES is composed of 'in-the-moment' and stable affective components called strands (e.g. goal or motivating desire, affective pathways, expression of affect, meanings encoded by emotions, meta-affect, self-talk or inner-speech; p. 549). These structures begin with a learners' emotional pathways, and archetype the corresponding behavioural dynamics. Goldin and colleagues' earlier work on systems of affective representation evolved from mapping emotional sequences (affective pathways) whilst solving mathematics problems, to considering a problem solver's emotions about emotions (meta-affect; Schlöglmann, 2006).

Most scholars researching affect focus on individual affective traits, such as selfefficacy, values and beliefs (DeBellis \& Goldin, 1997, 2006; Schlöglmann, 2006; Weber, 2008). For example, Weber's (2008) research collected data by occasional interview over several months, and therefore reveals more about longer-term affect. These researchers build on prior substantial psychological research that indicates that expression of positive emotions whilst communicating is supportive of engagement within a broader understanding of behaviours, as 'ways of being' (Schutz, Hong, Cross, \& Osbon, 2006). Such research positions emotions as ways for learners to gain satisfaction, and are associated with identified primary emotions. One notable associated shift in this research is from Liljedahl (2005). He found that restoring a productive pathway needed only one event (e.g. the 'Ah-ha!' moment) rather than repeated events as Goldin had suggested earlier. If such 'Ah-ha!' moments are indeed pivotal, then one may hypothesize that exploring one's rapidly changing "in-themoment" affective states (demonstrated via external expressions of emotions, such as facial expressions, body language, exclamations, etc.) may hold the potential to be an important point of reflexivity and overall satisfaction for teachers engaged with mathematics. However, the literature has been relatively silent on any examination of the temporal emotive dimension in learning environments, and particularly for 
teachers with different experience levels and across a myriad of teacher education contexts and venues.

Secondly, we drew on literature that situates teachers' practice and behaviours as part of their learning trajectories and continuous professional development as a means of improving teaching practice (Desimone, 2009). Teacher professional development is a process that addresses both teachers' developmental progression and their instructional practice, as they both intersect (Flores, Park, \& Bernhardt, 2016). Teacher instructional behaviours have three dimensions: affective, cognitive, and motivational. Internal framings of teacher practices, and behaviours, are rarely guided by what they know (cognitive domain), but more by what they feel (affective domain) or need (motivational domain; Korthagen, 2016). In this kind of research, teacher behaviours relate to fixed affective traits like (conscious and unconscious) beliefs, attitudes, and values (Goldin, 2014; Lazarus, 1991), or how such emotional traits relate to teachers' needs or motivational desires (Goldin, 2015; Mansfield \& Volet, 2010). However, external framings of teacher behavioural practices are mediated by their own history and disposition as learners (Hollingsworth, 1989; Zeichner \& Gore, 1990) and teachers (Borko, 2004), as well as their sociocultural and sociopolitical contexts, be it at classroom, school, or district level (Darling-Hammond \& McLaughlin, 1999) or because of accountability conditions at these multiple levels (Desimone, 2009; Spillane, Halverson, \& Diamond, 2004).

Scholars utilizing a situated view of learning environments often seek to gain a deeper understanding of affect (Borko, 2004; Greeno, Collins, \& Resnick, 1996; Lave \& Wenger, 1991) from a sociocultural (Cobb, 1994; Kelly, 2006), socio-political (Borko \& Putnam, 1996; Cohen \& Ball, 1990), and socio-mathematical standpoint (Patrick, Ryan, \& Kaplan, 2007). For example, Verner, Massarwe, and Bshouty (2013), in applying ES to their teacher candidates' affect while problem solving in a mathematics methods course, added a new structure based on their candidates' values and beliefs, and called it 'Respect My Culture.' Indeed, numerous scholars have opined on the importance of socio-cultural dynamics behind classroom transactions; respect, for instance, has been a posited as a key tenet for establishing equitable and engaging environments (Delpit, 1995; Freire, 2005; Milner et al., 2003; Nieto, 2003). In fact, "warm demand," is a teaching practice often associated with nondominant teachers' dispositions of both offering respect, and demanding it (Cooper, 2003; Gregory \& Weinstein, 2008; Howard, 2001; Kleinfeld, 1975; Monroe, 2005; Ware, 2006).

The versatility and potential of ES as a tool for modelling teacher professional development is important. Indeed, our future intention is to develop such a model in response to Goldin's (2014) call for "research-based professional development of mathematics teachers that addresses the affective domain." (p. 410). In an effort to pursue this, in this paper we aim to examine the original ES model as proposed for students in 2011 by Goldin and colleagues in two ways. First, we considered the model's potential as applicable to different internal and external framings of mathematics teaching environments. For example, Lewis (2013) and Verner et al. (2013) have already demonstrated ES's degree of portability out of the US city context and within K-12 and post-secondary mathematics classrooms. Secondly, 
Table 12.1 An example of one of Goldin et al.'s (2011) engagement structures in tabular form

\begin{tabular}{|c|c|c|c|}
\hline ES & Key strands & Description & Additional information \\
\hline \multirow[t]{5}{*}{$\begin{array}{l}\text { Get The Job } \\
\text { Done (GJD) }\end{array}$} & Desire & $\begin{array}{l}\text { To complete an assigned } \\
\text { mathematical task } \\
\text { correctly, following given } \\
\text { instructions, thus fulfilling } \\
\text { an implied obligation. } \\
\text { "The motivating desire } \\
\text { for task completion in Get } \\
\text { the Job Done may evoke } \\
\text { more procedural, } \\
\text { time-efficient strategies or } \\
\text { algorithms." (p. 552) }\end{array}$ & $\begin{array}{l}\text { Belief that mathematics } \\
\text { is mainly procedural, } \\
\text { answer orientated and } \\
\text { rule governed, requiring } \\
\text { thoroughness, with given } \\
\text { directions from an } \\
\text { authority. Meeting } \\
\text { expectations and } \\
\text { compliance are valued }\end{array}$ \\
\hline & Need & $\begin{array}{l}\text { What Murray calls } \\
\text { deference: "to yield to the } \\
\text { influence of an allied } \\
\text { other." (p. 154) }\end{array}$ & \multirow{4}{*}{$\begin{array}{l}\text { Get The Job Done allows } \\
\text { a person "with such } \\
\text { beliefs to use his } \\
\text { knowledge to complete } \\
\text { the task procedurally, if } \\
\text { possible; to ask for } \\
\text { step-by-step help..., and } \\
\text { to detach from further } \\
\text { cognitive engagement, all } \\
\text { without calling his } \\
\text { beliefs into question." } \\
\text { (p. } 557 \text { ) } \\
\text { One may set out to Get } \\
\text { The Job Done, but notice } \\
\text { along the way that he } \\
\text { understands something } \\
\text { another person does not. } \\
\text { Initially, Let Me Teach } \\
\text { You becomes active in } \\
\text { task completion. The } \\
\text { imparting of } \\
\text { understanding becomes } \\
\text { the major motivating } \\
\text { desire, with the goal of } \\
\text { simply completing the } \\
\text { assigned task no longer } \\
\text { salient: Get The Job } \\
\text { Done has branched into } \\
\text { Let Me Teach You }\end{array}$} \\
\hline & Evoked by & Being given directions. & \\
\hline & Behaviour & $\begin{array}{l}\text { "Oriented toward } \\
\text { straightforwardly carrying } \\
\text { out the work. In group } \\
\text { work, others may be } \\
\text { enlisted in this goal." } \\
\text { (p. 553) }\end{array}$ & \\
\hline & Emotional satisfaction & $\begin{array}{l}\text { From fulfilling the } \\
\text { obligation through task } \\
\text { completion, not } \\
\text { necessarily from } \\
\text { mathematical learning. } \\
\text { Different ES may evoke } \\
\text { different meta- affective } \\
\text { responses. For example, } \\
\text { when Get The Job Done is } \\
\text { active, frustration is likely } \\
\text { to be experienced and } \\
\text { related to fulfilling the } \\
\text { motivating desire }\end{array}$ & \\
\hline
\end{tabular}


a wider aim is to explore any mapping of emotions between teacher and student, as patterns emerging for any individual might act to facilitate or block the experience of emotions (for teachers and for students) as engagement is a bi-directional transaction between them (Boykin et al., 2011). In other words, studying teachers in action may offer a means of exploring how teacher affect relates to classroom 'transactions' between teachers and learners (Boykin et al., 2011). Exploring the compatibility of the ES model for this purpose is a crucial first step. In the first study, we drew our cases from how the inferred ES were activated and how they interacted. In Table 12.1 we summarize examples of how the ES of Get the Job Done can be activated, as this ES is central to the descriptive cases of both Mykia and Adam (for more details on other ES see Goldin et al., 2011 and Schorr et al., 2010).

It is important to note that unlike affective traits, affective states are by no means static, thus ES are similarly not static although at any one moment there is a dominant emotionally directive one (Goldin et al., 2011). Thus though the existing ES model applies to teachers (see Lake \& Nardi, 2014), as we will demonstrate through the cases of Mykia and Adam, there may also later prove to be significant differences in what positions are available, and hence which ES are accessible within mathematics teacher identities.

\subsection{Methodology}

\subsubsection{Research Question}

The primary question driving this paper is: in what ways can the description of teachers' activated ES be used as a tool to examine the powerful mathematical affect teachers demonstrate when teaching across different mathematics classroom environments?

\subsubsection{Study Design}

In this paper we draw on two studies that sought to explore mathematics teachers' praxes and affect. The first study sought to explore novice teachers' affect as part of their clinical practice (Dieker, Rodriguez, Lignugaris-Kraft, Hynes, \& Hughes, 2014). Twenty-one novice teachers (NTs) were observed (18 females; 3 males; all African-American). These novice teachers were enrolled in the third year of an elementary mathematics education practicum methods course which included 32 hours of clinical practice, at a Historically Black University in the United States. As part of a modified "lesson study" (Puchner \& Taylor, 2006), the teacher educators collaborated with novice teachers to design a 90-minute lesson based on fractions that aligned with the Common Core State Standards of Mathematics. Fractions have been 
proven to be a conceptually challenging topic for elementary teachers (Lee \& Boyadzhiev, 2013), and researchers have shown that assigning the topic for rehearsals allows novice teachers to focus on how to teach as opposed to what to teach (Dieker et al., 2014). The NTs were asked to design their lesson using the 5-E Learning Cycle (Bybee, 2015), and based on feedback from the teacher educator on the lesson plan, NTs revised and then selected 15 min of what they considered to be engaging instruction to rehearse in TeachLivE ${ }^{\mathrm{TM}}$ whilst being video-taped. Rehearsing in a simulated classroom environment like TeachLivE ${ }^{\mathrm{TM}}$ (Dieker et al., 2008), a mixed-reality classroom setting where a teacher can practice instruction strategies by engaging with students presented as avatars. TeachLivE ${ }^{\mathrm{TM}}$ allows teachers to rehearse instruction in a 'safe' environment, where circumstances are more controlled by the simulator to elicit emotional responses and behaviours from the teacher (Dieker et al., 2014). For example, the 'urban' level exhibited in the TeachLivE' evoke teachers' responses to student avatars who offer a degree of scepticism and dissent, engaging in questioning and exhibiting more expressive behaviours in the classroom setting. Learning to teach in 'safer' and 'easier' conditions may then positively affect teachers' overall job satisfaction and retention, which is why clinical work is considered by many to be the most influential component of teacher education programmes (Ronfeldt, 2012). However, "teacher education programmes [have yet to] move from changing beliefs per se to making teachers aware of beliefs and other factors affecting practice" (Goldin et al., 2016, p. 24).

The second study sought to explore eight experienced teachers' affect whilst teaching a mathematics lesson as part of their role as secondary school teachers in the UK. The sample was drawn from a relatively rural area in England, and was collected early in the school year when norms were being set for classroom engagement. This predominantly qualitative research explored the interaction of teachers based on episodes indicating a productive affective interaction. These were identified as incidents of smiling or laughter, or body language. The primary question addressed the wider research question of how teachers productively use positive emotions within their teaching to support student learning and to encourage engagement in mathematics. In addition to interviews to document their professional life history and to ascertain wider views and beliefs about the teaching and learning of mathematics, teachers were observed during normal mathematics lessons and were later provoked into revealing their experienced emotions by watching video clips from the observations during stimulated recall interviews.

\subsubsection{Participant Context}

In the first study, Mykia, a novice teacher, prepared a lesson plan based on several iterations of feedback from the teacher educator. She then selected $15 \mathrm{~min}$ of instruction from her lesson plan to rehearse in TeachLivE ${ }^{\mathrm{TM}}$. After rehearsing, Mykia received feedback and coaching from two teacher educators and reflected on her experience in a journal. She then revised and re-taught her 15-minute lesson plan to get feedback, 
and again reflected on the experience (30 min of teaching; two times of feedback from teacher educators; two post-rehearsal journals).

In the second study, Adam, an experienced teacher with a management role, has taught the same lessons many times over in more than 8 years of teaching and hence is ideal to compare and contract with Mykia. Adam was observed on several occasions, teaching the same class (aged 14-15), but for different curriculum topics. These included a discussion of upper and lower bounds, sequences, or how to construct a stem and leaf diagram. In the data collected for Adam, for this paper, we draw on interview reflections on his teaching as a whole prior to observation, and from his reflections specifically focussed on four lesson episodes in a series of videostimulated post-observation discussions.

\subsubsection{Data Sources and Analyses}

Despite differences in purpose in gathering the data and some differences in the analysis methods, the two research designs combined in this paper have striking similarities in the inferred ES. These similarities indicate an applicability of the model that has useful implications for further research, as can be seen from the discussion below despite the fact that the UK study of experienced teachers was smaller and studied each of the teachers through initially identifying affect. This agenda contrasts with the US study, which had an additional agenda of novice teachers' self-efficacy development. Data analysis involved first contextual analysis of each teacher's mathematical autobiography/life history, video transcripts of rehearsals/teaching and post-teaching reflections through journals or interviews.

In both predominantly qualitative studies, the researchers cycled through the data set and created tables and analytic matrices (Creswell, 2009) to compare teacher candidates' motivating desires, behaviours, and beliefs during teaching. The focus on these strands, as described above, is specifically to understand the patterns and themes of each teacher's affective experience whilst teaching.

Document analysis of video transcripts and post-teaching journals or audiorecorded reflections were conducted, where coding served to search for further evidence of teachers' ES. In the first study, to establish inter-rater reliability, videos were coded by two research assistants and then by two researchers (Miles \& Huberman, 1994). The researchers first coded videos by searching for instances of the nine ES from the Goldin et al. (2011) study, then further coded each ES to find evidence of the seven "in-the-moment" interacting strands (i.e. the goal or motivating desire, affective pathways, expression of affect, meanings encoded by emotions, meta-affect, self-talk or inner-speech) for each structure as emerging ES patterns and themes were identified. In the second study, the preliminary search sought instances of emotional expression by the teacher; the second stage was to seek evidence of the interacting strands to associate with ES.

The outcome is two levels of analysis, both of which identify dominant ES. In the first study, we have ES associated with shifts within the minutiae of lesson inter- 
action, whilst in the second study, we see how ES apply to a short affect focused episodes of around two to three minutes. Self-reported autobiographical data and post-observation data from Mykia's journal reflections after rehearsing in TeachLivE $^{\mathrm{TM}}$, and Adam's post-observation commentary, along with coded video transcripts and the researcher's' participant observation, all served to triangulate data points to describe Mykia and Adam's in-the-moment ES as they taught a mathematics lesson. In the following paragraphs, Mykia's and Adam's mathematical affect are described; followed by a snapshot of the activated ES whilst teaching a mathematics lesson. Then, given the purpose of comparing and contrasting the teachers' experiences, we will next describe each teachers' ES (Mykia, then Adam) before discussing the implications.

\subsection{Mykia's Powerful Mathematical Affect}

Mykia showed consistent evidence of Goldin et al.'s (2011) ES. Mykia's evolution from demonstrating ES affiliated with more in-the-moment negative emotions, such as Stay out of Trouble, Don't Disrespect Me, It's not Fair, and Get the Job Done whilst in the first rehearsal, to ES with a more positive affect in her second TeachLivE ${ }^{\mathrm{TM}}$ rehearsal, such as Let Me Teach You, Check This Out, and I'm Really Into This, Look How Smart I Am is evidence of how affective states may be linked to affective traits such as self-efficacy. Mykia's personal experience spoke to how she wanted to "never deter students from learning," as she "hope[d] to be the most influential and inspiring teacher they've ever had." Her passion for becoming an educator was revealed by her enthusiastic reflection, "Every experience I've had inside the classroom is so fulfilling and exciting for me and I can't wait until I can do this every day of my life."

Mykia exemplifies the potential Goldin et al.'s (2011) ES pose for teacher development because rehearse teaching was a turning point for her (see Khalil \& Hughes, 2016 for details on NT self-efficacy increases). Mykia's affective experience in her first TeachLivE ${ }^{\mathrm{TM}}$ rehearsal boosted her belief in herself and her ability to teach mathematics: "TeachLivETM rehearsals boost my readiness and confidence in what I am teaching." Prior to her first rehearsal, Mykia's engagement with mathematics problem solving, ideation, or identification was rife with deeply embedded anxiety that overshadowed how she engaged with any part of the mathematics methods course. As she reveals in her mathematics autobiography, "When I think about math, long, drawn out equations and formulas that seem impossible pop into my head and I can't help but to become a little anxious."

In fact, one week prior to her first 'real' teaching experience, (i.e. her TeachLivE $^{\mathrm{TM}}$ rehearsal), she approached one of her instructors and said she was considering withdrawing from the class. This was a surprise for the instructor, who, despite recognizing Mykia's anxiety and prior negative affective experiences in mathematics as a learner, thought those emotions were an asset, as it seemed to motivate Mykia's strong performance in class. Furthermore, the instructor hoped that by helping teacher candidates reflect on conceptual and productive struggles in mathematics, 
teacher candidates' beliefs equating mathematics fluency with speed would change. Furthermore, the evaluation of Mykia's conceptual and productive struggles in mathematics support further research into these effects in an assimilated 'real' classroom.

In her mathematical autobiography, Mykia's self-efficacy and self-identity as a mathematics learner were very much about her perception of time on task, and her speed in relation to others. She noted that she, "loved mathematics [in her primary years] because [quick computations] was something that [she] was good at, whereas when assigned work that would take hours to complete, [she thought that she] never wanted to take another math class, especially with Mr. Wang."

However, she alluded to moving beyond such beliefs when she noted that she "can't always run from challenges," noticing the rewards of perseverance:

I completely grasped every concept Mr Wang taught us and even excelled on the AP Exam as most students at my school did not pass. I am so glad I stuck it out and stayed in the course. It's an amazing feeling to do well in something you're so used to doing poorly in.

Being able to understand and learn how to push through challenging mathematics tasks became a motivational desire for Mykia to complete Mr Wang's class. Many of the ES Mykia demonstrated during her TeachLivE ${ }^{\mathrm{TM}}$ rehearsals were similarly characterized by her belief systems (e.g. perception about time as it relates to her teaching performance), whilst others were more related to her "in-the-moment" emotion. However, it was Mykia's meta-affect and the sequence of her emotional states interacting with the heuristics of lesson planning and rehearsing mathematics, which ultimately led to her 'Ah-ha!' moment that she can teach mathematics (Goldin, 2000; Liljedahl, 2005).

\subsubsection{Evidence of Mykia's Engagement Structures}

Consistent with Mykia's overall affect as it related to mathematics, our characterization of Mykia's first rehearsal illustrates a dominance of the Get the Job Done engagement structure. Evidence of Mykia's Get the Job Done was inferred when she exhibited a focus to persevere through an explanation of her "butterfly method"(a mathematics procedure used to find the common denominator of fractions) during her rehearsals, despite a student's incredulous question, "Is this part of the class?" Mykia's expressed her motivating desire was to get through the entire lesson first, as her performance goal to teach was construed by us as a behaviour about her interaction with the mathematics lesson and less about students' learning. Mykia's pattern of behaviour during this activated ES involved her speaking quickly and rushing through the lesson, without acknowledging any further questions from her students, and solving all parts of the lesson's problem without attending to a bidirectional engagement with students. This hyper-focus may have been in deference to the instructions to complete a 15-minute rehearsal (instructions she felt obliged to comply with). Mykia reflects, 
I was able to get through the lesson, but if I paced better, I could have finished and done more examples for knowledge checks of the tools I had just taught.

Indeed, we suggest the "motivating desire for task completion evoked more procedural, time-efficient strategies" (Goldin et al., 2011, p. 552) such as Mykia's fast-paced instruction and dogmatic perseverance to comply with her image of a what a teacher is to accomplish, i.e. to 'deliver' a lesson, are evidence of the interaction strands of the Get the Job Done ES. However, her lack of attention to students' questions may indicate the engagement structure, Don't Disrespect Me, may also have become active as ES do not occur in isolation.

The engagement structure Don't Disrespect Me seemed equally dominant in Mykia's first rehearsal, and was illustrated through Mykia attempting to establish control of the classroom discourse. Early in her first rehearsal, when a student asked Mykia the question "Why do I even have to learn this?" She hesitantly replies, "Excuse me Kevin? No, I will address questions at the end." Mykia's motivating desire was to establish a level of respect for herself by stating policies in a no-nonsense, assertive tone. However, her assertiveness had a quiet, proud quality to it, and in this engagement structure, her respect for students' sense of worth was evident as well. This value is reflected in her reflection, "I think it is very important to build students' confidence in every subject at a very young age. If the foundation is strong, then learning new concepts will always be fun and easy."

We infer that Don't Disrespect Me was markedly evident even within the very short duration of rehearsals, and was characterized by Mykia showing respect for everyone's dignity, requiring it back, and providing a 'safe' mathematical space free of belittlement. Goldin et al. (2011) have suggested Don't Disrespect Me and Check This Out ES are central to students who may be attempting to assert their agency and identity when faced with possible scepticism or dissent around their mathematical decisions. In a similar vein, the avatars were designed to evoke a similar behaviour from the teacher candidates when their instruction was questioned. We suggest evidence of this was when Mykia felt the need to "save face" when challenged by her students. Whilst Mykia exhibited an external expression of frustration at being challenged by a student's combative question, Mykia's motivating desire was to meet the perceived challenge this particular student posed by "shut[ting him] down." We inferred Mykia's external expression of affect from her elevated tone and punctuated body language which seemed "socioculturally dependent as well as idiosyncratic" (Goldin et al., 2011, p. 553). However, in her post-teaching reflection, Mykia noted;

\footnotetext{
Although I was able to shut all these [student distractions] down within the first few minutes, I heard that they were worse with some of my classmates. I see how important it is to incorporate tasks that really engage the students so you can have their undivided attention for the time that you have.
}

This comment exemplifies some of the encoded meaning behind her expression, as it was at once a way to protect herself from perceived loss of worth, whilst protecting students' sense of worth. Thus, when challenged further, Mykia's self-concept had her assertively and competently replying: 
Student: What does the body of the fraction supposed to mean?

Mykia: You will learn that in a second!

Whilst assertive, Mykia's tone was not expressed in a way that may insult students for asking. By virtue of being in a rehearsal, Mykia also seemed to exhibit the engagement structure Let me teach you, where she wanted to demonstrate her mathematics ability to herself, the avatar students, and her instructors. For example, through a series of questions, Mykia's exhibited that her motivating desire, a mastery goal, was to be able to help a confused student understand how to transform an improper fraction into a mixed fraction. Mykia scaffolded questions in a patient, warm tone, and demonstrated the steps to explain the solution to the problem. This activated engagement structure, exhibited midway through Mykia's first rehearsal, seemed to be a pivotal moment for Mykia, as she began to believe she can teach.

Pressing forward in an attempt to teach fractions procedurally through the "butterfly method," where the "butterfly" outline is a notation of cross multiplication to find a common denominator, Mykia prepared a poster with a butterfly to illustrate this technique of adding fractions. Although Mykia's use of this practice may not be a conceptually demanding mathematical practice, it would seem the Check This Out engagement structure was activated by the opportunity to express herself artistically through a familiar mathematics strategy. Perhaps Mykia's return to familiar strategy to find a common denominator is what she needed for her affective development, as it motivated her to engage in the Check This Out ES, which may in turn have been the incident that helped improve her self-efficacy (see Khalil \& Hughes, 2016 for details). Furthermore, this engagement structure may be linked to Mykia's intrinsic motivation of meeting the challenge to provide clarity to difficult mathematics problems.

Thus, Mykia's motivating desire, the intrinsic reward, associated with the "informing function" (Zimmerman \& Schunk, 2008, as cited in Goldin et al., 2011, p. 553), was seen when Mykia assisted CJ, since CJ struggled the most during the lesson. Mykia found it enjoyable to know that $\mathrm{CJ}$ was gaining the information and learning from her butterfly fraction method. The external emotions she seemed to exude included excitement and enthusiasm, and it was evident in her tone of voice that she was enthusiastic about having the opportunity to help teach a struggling student master the content (a mastery goal). Mykia's dialogue with CJ suggested her possible payoff for offering a new perspective to $\mathrm{CJ}$ are more consistent with the Check This Out engagement structure.

Mykia: What is a benefit of what you learned from the lesson today, CJ?

CJ: You drew a butterfly...I don't know, what she said (pointing to the student that answered before him).

Mykia: Ok, what was the purpose of the butterfly?

CJ: To learn how to add and subtract fractions.

Mykia: Good Job!

The ES Check This Out and Let Me Teach You both suggest that Mykia's "beliefs have reciprocal influence on [her] in-the-moment mathematical engagement" 
(Goldin et al., 2011, p. 556), and thus may prove to be very powerful affective structures for understanding teachers' adaptivity. However, by far the most often inferred engagement structure in Mykia's first rehearsal was Stay out of Trouble, where Mykia avoided interactions that may lead to distress. For example, we hypothesize Mykia avoided feeling vulnerable in her inability to answer a question (performanceavoidance goal), perhaps due to her initial self-concept that she has low capability. However, this engagement structure quickly turned into Don't Disrespect Me, as students took Mykia's initial sign of vulnerability as an open sign to challenge the premise of the teacher's mastery of the topic.

The final engagement structure that was activated in Mykia's first TeachLivETM rehearsal was It's Not Fair. Here, Mykia showed signs of unhappiness with rehearsing with avatars, as opposed to K-12 students in the field, as she described their disengagement and her lack of ability to use proximity as frustrating. For example, Mykia found it unfair that a particular student continued to disengage in classroom instruction, whilst the rest of the class participated in the discussion and were "alert and ready to learn." Therefore, Mykia's motivating desire was to involve this student in participation of the lesson. The unresponsiveness of the student (head on the table and not moving) evoked frustration, evident in Mykia's behavioural patterns, as she perceived the student's noncompliance as unfair to her demand of other students' attention. Mykia addressed this inequity by insisting the student, Maria, participate in the class activity, exclaiming: "Maria, I need you to wake up?!" During this time period, it is possible that Its Not Fair and Get the Job Done were operating simultaneously, as there was little that could be done to restore her sense of fairness in addressing disengagement from an avatar student. Therefore, this may have influenced Mykia's motivating desire to fulfil a performance goal of finishing the lesson (Goldin, 2014).

In the second rehearsal, the change in Mykia's beliefs about her mathematical ability to teach had changed to one where she did believe she can teach. This change led to more activation of the ES Let Me Teach You, I'm Really into This, and Look How Smart I Am. Noticeably, fewer incidents of ES that may have been associated with her former lower self-efficacy, such as Get The Job Done, Stay Out of Trouble, or Pseudo-Engagement were evidenced in the second rehearsal. Evidence of the activated ES Mykia displayed in her second TeachLivE ${ }^{\mathrm{TM}}$ rehearsal included Let Me Teach You, where she used re-voicing as a way to explain concepts to Kevin and CJ, and I'm Really Into This, as she focused more on teaching mathematics than on student participation. She also showed more instances of Look How Smart I Am. All three of these ES are about "communicating mathematical ideas, and explicitly incorporat[ing] affective, cognitive, and behavioural components" (Goldin et al., 2011, p. 556). As Mykia stated:

I felt more comfortable in my knowledge of the information and was able to teach without the visual aid I prepared. I think I was effective in meeting my objectives. The students were able to answer all of verbal summative and formative assessments during and after my lesson. The students were able to recall information, including definitions and steps of the butterfly method. 
Thus, when the students, Kevin and CJ, struggled to understand the questions to arrive to an answer, Mykia's motivating goal was first to transform a mathematically challenging learning environment into a productive challenge for the student (Let Me Teach You), and second to attend to the "imparting of understanding" (Goldin et al., 2011, p.555). Thus, when a student was reluctant to provide an answer, Mykia used her meta-affect of what she experienced in the first rehearsal to transform the experience from a difficult learning situation into a productive experience for the student. Therefore, Mykia's behaviour patterns changed by explaining and demonstrating problem-solving techniques for the student, with her satisfaction derived from governing student engagement more effectively with the mathematics, and ensuring students understand the mathematical problem.

Mykia: First I would like to go over the numerator of a fraction. Kevin, what is the numerator?

Kevin: I don't know

Mykia: Can you give me a guess?

Kevin: It's like part of a fraction or something

Mykia: Right, it is a part of the fraction, it's the top number of a fraction

According to Goldin et al. (2011), individuals that evoke the Let Me Teach You ES may gradually branch into a Look How Smart I Am, as we believe achieving emotional satisfaction and affirmation from her students helped Mykia to focus on the procedural fluency of the butterfly method.

It is noteworthy that Mykia's feelings of comfort whilst rehearsing improved her overall affect and led to the appearance of ES that were more intrinsically motivating for her. Mykia displayed several moments of I'm Really Into This, where she exhibited interest or "flow" (Csikszentmihalyi, 1990) in explaining operations with fractions to the point she seemed almost oblivious to the presence of the avatar students and the passing of time as she focused more on her teaching than on time completion or classroom participation. Once the students mastered the process and began to appreciate how the method resembled a butterfly, Mykia expressed pleasure in the students' engagement. Mykia's external emotions were evident in her facial expressions and body language. Here is an excerpt of the pride she viscerally exemplified for the I'm Really Into This ES:

Mykia: First step is to add the body to your fraction. To add the body you will draw a wing around the denominator of the first fraction and the numerator of the second fraction.

Student: It's a butterfly!

Mykia: Right, it is a butterfly! So as you did here, you add the antennas next. Now we will get to the math.

Ultimately, Mykia describes her happiness with the flow of her second rehearsal teaching session, stating:

The delivery was more genuine and I believe the students took well to my lesson, because I didn't have to focus too much on classroom management as I did the first time and the students responded better overall. 
She went on to explain,

This is one lesson that after taking the critique I received the first time and using that to improve, I felt extremely comfortable in my delivery and I believe the students learned what I expected them to at the end of it all.

Thus, Mykia's increased attention to areas she could improve on from her initial feedback allowed her to become more enthusiastic about her delivery of her lesson plan. The constructive feedback she obtained from TeachLivE ${ }^{\mathrm{TM}}$ rehearsals provided Mykia a higher positive self-regard for her abilities to perform teaching fractions (Liljedahl, 2005) and coincided with the ES Let Me Teach You, I'm Really into This, Look How Smart I Am. and Check This Out. Whilst there was an instance of Don't Disrespect Me in the second TeachLivETM, the majority of the ES were about "service [to the] group's task completion" (Goldin et al., 2011, p. 555) rather than other ES that were motivated by the teacher's performance-avoidance goals and less productive "in-the-moment" affect.

\subsection{Adam's Mathematical Affect}

Turning to Adam, who, as discussed above, provides a contrast to the less experienced Mykia, we first outline how ES appear in the data collected for Adam.

The overall impression given by Adam was of confidence. The dominant activated ES for Adam were Let Me Teach You supported by Look How Smart I Am, Check This Out and I'm Really Into This, with indications of Get the Job Done. Examples of these are drawn from four illustrative episodes selected as showing emotions deemed powerful through tone, body language, and observed laughter and banter. Adam predominantly used language, tone, emphasis, and tempo to convey this, as a faster pace tended to indicate, or at least give an impression of increased engagement and interest.

Within each of three observed lessons, Adam's teaching style was composed of different phases, each with a specific tempo and agenda that are combined to develop a mathematical storyline for his students. He engages in 'in-the-moment' behaviours, acknowledging by eye contact, use of 'we' to include the students as audience, and facial expression as reactions to student contributions, thus maintaining his approachable style. He seems comfortable with breaking the mathematical storyline, not trivially, but with substantial deviations, a characteristic with an observable affective impact if student aligning responses and laughter are indicative. For example, in one lesson Adam deviates extensively into a scenario about counting sheep to reinforce the meaning of $n$ within sequences. This deviation occurs within a lesson where the main storyline centres on generating the rule for a given sequence of numbers. Adam, in interview, tells a story about when his school was short of mathematics specialists as they struggle to both recruit and retain qualified teachers (Fisher \& Royster, 2016). The story illustrates his unease with just Getting The Job Done, as that ES gives him little pleasure in his teaching, saying, "Um...so you kind 
of lose some of the nice bits of the job, all the perks, all the nice feeling, if you are just trying to get the job done." This sentiment speaks to the stress many teachers feel due to the high-stakes mathematics they teach, where even experienced teachers are vulnerable to the continuous onslaught of new requirements and standards (Borko, 2004).

As well as using expressive vocal tone and emphasis to stress mathematical points, Adam's speaking pattern contained more observable emotions, compared to other parts of the lesson. The pace in these parts of the recordings became slower and more repetitive. His voice had contrasting volume, and became louder for significant junctures in mathematical explanation. It is likely that students, exposed to this pattern regularly, would soon 'tune in' to what he intended to highlight as important. To illustrate this, in a lesson about upper and lower bounds, he broke his speech into a rhythmic beat to provide emphasis, not once, but in a repetitive pattern, as he said "as big as possible." This could be heard as as-big-as-poss-i-ble, divided into six equal rhythmic beats. The effect is to highlight the importance of this part of the communication. In the video, Adam appeared able to focus single-mindedly on a task, a behaviour exhibiting a desire to experience flow, defined as complete absorption in what one does and tuning out of the rest of the world (Csikszentmihalyi, 1990).

In post-observation discussion, Adam described his perceived expected behaviours for a mathematics teacher: to satisfy student need for achievement through task completion via engaging pathways, perhaps with less regard to whether, or what type of learning, is achieved. One of the conventional 'expected' behaviours and social interaction rules for mathematical success is quickness (Black, Mendick, \& Solomon, 2009). Adam felt the need for completion of activities, even if it meant de-prioritising other aspects of learning, thus perhaps valuing utility. The issue of pace troubled him, as he returned to this theme often in the interview, saying "I was talking quite a lot and we weren't getting through the content as quick as we should have done." Similarly, Adam may have experienced some discomfort or frustration in that the students did not have enough consolidation time and there would not be enough time to round off the lesson properly, “...in the normal way...I think that I was also aware that again I hadn't [...] kind of switch off and just sit and let them do something for a longer period of time...."

The lesson observation data suggests Adam inhibited student deviation by body language and gesture, or by comments or questions, in order to complete tasks quickly. He placed emphasis on pace, and identified examples of competitiveness both in mathematics and in administrative tasks. He talked of losing some of his own faith in mathematics, exactly when he was challenged at university and could not perform highly enough to meet the demands of this competitiveness, an indicator that reveals a deep perception of equating mathematical fluency with speed.

Adam also appeared to find personal satisfaction in his own successes, both intrinsic and extrinsic. The satisfaction of mastery in teaching skills was illustrated through his use of idiosyncratic, observable yet often subtle, use of gesture and interjections. This use was frequently used to modify unwanted student behaviour. His external expressions of emotion included laughter and smiles, raised eyebrows used to encour- 
age questions, and rapid and emphatic use of body movement. The gestures were quickly executed and indicative of strategic 'norms' for the group. For example, he used a rapid and directed 'Shh' for seeking the attention of the class, and he used the word 'travellate' (Subsequently, this was identified as an abbreviation recognisable to students as "traffic light your objectives"), which had meaning for this class (they were expected to assess their learning), and all students promptly responded as expected. This well-established belief is evidenced when he talks about his own achievements, in particular the frequent use of a contented ' $\mathrm{hmm}$ ' when he is proud of a remembered experience. Other examples include his statement that students liking mathematics because they also like him, which he found personally rewarding, "I think um [contented]...students I teach get that enthusiasm from me."

\subsubsection{Evidence of Adam's Engagement Structures}

Goldin et al. (2011) define Get the Job Done through characteristics such as deference to establishment and following of rules, often procedural. The evidence supporting this ES is led by a motivating desire to appease an obligation; to cover the prescribed curriculum. Some indication of this can be seen in the following:

Adam: Right guys. Pause on what you are doing. I'll show you something quickly to help tie this together.

And at another time,

Adam: $\quad$...well... have you done this before?

Students: Yeah

Adam: So, yeah, right, a quick recap on how they work.

Adam's expression of affect is supported by his pace and tone of voice. In an interview, Adam expressed unease with high-stakes mathematics, saying teachers lose the 'nice[r] bits' of teaching, but then also immediately justified it, saying "So for them to improve, it's often knowing exactly where they get the exam marks from." High-stakes mathematics, as an extrinsic motivation, may have lead Adam to disengage in longer discussions with his students, as evidenced by his non-verbal inhibitions of student questions as he attempts to cover the curriculum. However, Get the Job Done is not entirely satisfying for Adam, and there are more significant intrinsic motivators that drive his other ES.

A second activated ES Adam experienced is Look How Smart I Am. A teacher adopting such a structure, as in the case of a student, would try to impress with ability or knowledge, both highly valued, and would give value to increased selfregard. They would respond to an admiring audience and may have a performance goal orientation that includes competitiveness. In interview, Adam said, "I have just always excelled at maths, I could always do everything in maths lessons and I found other lessons quite hard." Competitiveness may be rooted in his stories about his early mathematical experiences. At about age 5, he says, in comparison to other 
children, Adam said, "I was just able to do it...I just got any kind of numbers or anything."

Yet Adam also exhibited elements of another ES, Check This Out, where value is given to utility, yet also to mathematics solely as an enjoyable experience motivated by intrinsic or sometimes extrinsic reward. This engagement structure includes both conscientiousness and consideration for what benefits there are in the activity. Adam shifted to a faster pace and a slightly louder voice for these points in the lesson, giving an impression of interest as he said, "Right! Think about this!"

To a lesser degree, there is some evidence of a further ES, I'm Really Into This in Adam's data. Goldin et al. (2011) suggest that the underlying need within this ES is for understanding, part of a mastery and goal orientation. Adam appeared to find satisfaction in the experience of teaching and in finding solutions to challenges within his role. For example, he appeared absorbed in what Amy, one of his students, was saying. This appeared as single-minded behaviour centred on the mathematics as displayed, with Adam saying, "Amy, the expert, is going to tell us about stem and leaf diagrams." In another observation, Adam showed complete absorption in the task at one point in the lesson, when he faced the board, muttered briefly to himself and was then silently absorbed, almost as if he was doing the mathematics on the board alone in the room, modelling I'm Really Into This. Later in the same lesson, his manner indicated excitement that the students had an opportunity to engage in challenging mathematics, saying, "This guys is where it's going to stretch..." These data suggest I'm Really Into This in a social sharing context.

Both ES, Check This Out and I'm Really Into This, are strongly associated with Adam's teaching. Yet the strongest match for Adam is with Let Me Teach You, with evidence widely occurring within the data, of a desire to help others understand and of adopting a position of nurturance. Adam especially showed satisfaction in fulfilling this desire, and that the belief that he will find gratification in a positive response or appreciation is well established. He commented after one lesson, "there's a little group and they're like, yeah, I really like maths [laughs] ... they like the subject... they like me as well."

\subsection{Comparison Points from the Two Case Studies}

Drawing together the data from the two studies provides insight into how ES might appear at different stages in a teachers' professional learning trajectory. It is notable that both teachers aspired to be motivational, that Adam retained enthusiasm and the desire to be a good teacher, and that the desire to be inspiring remained after so many years. Both teachers experienced turning points that influenced their approach to teaching, and the use of ES may support further exploration of the potential impact of such turning points, or Ah-ha! moments. The changes Mykia experienced in her affective states through participation in the TeachLivE ${ }^{\mathrm{TM}}$ rehearsals was also complemented by a significant improvement in her mathematics self-efficacy (see Khalil \& Hughes, 2016) and reform-based teaching (see Khalil et al., 2016). Evidence 
of Adam's pivot and improved affective traits, on the other hand, were grounded in his return and re-commitment to teaching after a short stint as an IT consultant. Having "kind of like lost the love a bit for maths...", Adam returned to the classroom when, as he says, he realised that other careers lacked the affective, cognitive, and motivational stimulation he thrived on. A further similarity between Mykia and Adam is the role of a past teacher in building their mathematical identity. For Mykia, this was Mr. Wang; for Adam, it was a school teacher he recalled, "just really clicked with him ... and [whose] style suited" him.

The activated ES of Get The Job Done draws attention to the role of time and the accountability of the role of a teacher as one of the constraints for all teachers, regardless of experience. For Mykia, Get The Job Done was centred on completion of the lesson in the given time; this time pressure had not lessened for the more experienced teacher Adam, who commented frequently on time both in his interview and in the lessons. They both spoke quickly and, most significantly, there were points where they both either deferred students' questions for later or inhibited questions. However, it is important to note that Get The Job Done was not dominant during all teaching episodes, but appeared when the pressures of accountability motivated them.

As an experienced teacher, Adam had some of the time-efficient strategies that Mykia had not yet developed, which was evidenced by the shorter time Adam had Get The Job Done as his dominant ES. He also saw how the expectations of curriculum and exam preparation might be met, and where he could allow time for discussion without longer-term implications. To point, in Mykia's second rehearsal, Get The Job Done was less dominant and she was more dialogic as she figured out how to manage her time more effectively and engage with the mathematics and the students in a more productive way.

Don't Disrespect Me was not a dominant ES for Adam, and this was similarly the case for the majority of the experienced teacher sample. However, he was observed several weeks into the academic year when perhaps the behaviour management strategies commensurate with Don't Disrespect Me would likely be already established. It could also be a result of his familiarity with the mathematics taught, or the sociocultural context in which he taught. Mykia did not have the advantage of mathematics teaching experience and; indeed, the behaviour "chosen" in TeachLivE "TM was a level 3 (out of 5), which meant avatar students behaved in ways to simulate an 'urban' environment (Enicks, Whitten, Morgan, \& Dieker, 2013). Despite the problematic nature that such a stereotype may mean, Mykia and several fellow novice teachers recognized the socio-cultural dimension of this affective domain (Goldin, 2014) that undergirded the behaviours that students in TeachLivE exhibited. Through an empathetic tone, Mykia and other novice teachers were able to address unwanted behaviour quickly, apparently effortlessly, and with an aplomb that belied their novice status. Perhaps the novice teachers' shared socio-cultural background as part of a non-dominant group aided their sensitivity to demonstrating and demanding respect (Freire, 2005), and enabled their recognition of students' behaviours as possible assets, as opposed to a deficit that needed to be 'managed'(Frey \& Doyle, 2001). Indeed, Verner et al. (2013), in applying ES to novice teachers' affect whilst prob- 
lem solving in a multi-cultural mathematics methods course, added a new structure, Respect My Culture, thus suggesting the social and cultural dynamics behind behaviours should be another integral part of examining classroom transactions.

It is also worth mentioning that Adam and his fellow colleagues may consider it unprofessional to show emotions that are evident in Don't Disrespect Me or other ES associated with negative emotional states as associated with the It's Not Fair and Stay Outof Trouble ES, as some of the characteristics could be perceived as an indicator of difficulty or inexperience with mathematical problem-solving. Alternatively, more experienced teachers may have more practice self-regulating as the daily teaching challenges become less and less daunting 'in-the-moment.' Indeed, Verner et al. (2013) discovered that a manifestation of ES evolved within the learning process, and was motivational for novice teachers in an ethno-mathematical teacher education course. Perhaps a third explanation is differences in familiarity with content and pedagogical content knowledge.

Both Adam and Mykia exhibited characteristics associated with the more productively orientated ES of Check This Out, I'm Really Into This, and Let Me Teach You, which may speak to their adaptive engagement with their mathematical practice. We would like to suggest that the dominance of such ES may have students, in the future, identifying Mykia or Adam as their significant role model. What may warrant further investigation is how these ES are connected to one another during a teacher's "in-themoment" practice, and how they may resonate with students' similar ES modelling. Thus what seems important is not only the ES but the dominance and combination of ES used within a teaching session, informed by the beliefs of the teacher.

\subsection{Discussion and Implications: Engagement Structures as Overarching in Mathematics Teaching and Learning}

In this paper, we explore the emerging usefulness of ES as a framework to understand Mykia's sociocultural (Cobb, 1994; Kelly, 2006), socio-political (Borko \& Putnam, 1996; Cohen \& Ball, 1990), and socio-mathematical (Patrick, Ryan, \& Kaplan, 2007) engagement with teaching over two rehearsals, and compare Mykia's emerging practice to Adam's more established teaching practice. The importance of teachers attending to their affective domain whilst teaching has been shown to illuminate change in attitudes and beliefs of 'resistant' teachers (Liljedahl, 2005). Teachers that transform their attitudes and beliefs towards the learning of mathematics create instances of what Liljedahl calls Ah-ha! experiences of insight. These can serve as a valuable resource in fostering mathematical performance. It seems reasonable to suggest new teachers experience more such moments. These Ah-ha! experiences were evident through Mykia's first rehearsal, and the benefits of her positive beliefs about mathematics and her ability to do mathematics was evident in her second rehearsal. We might then assume that for the contrast of Adam, that he had prior 
experience of many Ah-ha! moments, and what we see in the data are the longerterm adjustments following such experiences.

If we consider the above discussion in terms of how ES are underpinned by teachers' motivational needs, which then activates the ES, then there is also a recognition of a driving need to reconcile the disparity between each teacher's existing perceptions of their teaching and their motivation to become what they perceive to be the ideal teacher. Both give importance to modelling enthusiasm, and this must inevitably inform the ES. Krzywacki and Hannula (2010) explored the existing and ideal self and the gap between these two selves that evokes needs. Horn, Nolen, Ward, and Campbell (2008) specifically discussed this in terms of teacher development, where they explored what new teachers see as the ideal teacher. They concluded that the most effective development resulted from experiencing tensions caused by gaps. This seemed to spur teacher's developing pedagogical reasoning, as well as their adaptability and coordination.

There are many implications from approaching classroom analysis using ES and examining the emergence of teaching from a temporal lens. We propose that ES can be used as a lens into teacher development that connects affective and motivational domains to their mathematical behaviours across the teacher professional learning trajectory. We believe that ES can be used in teachers' affective development as an 'active learning' tool, where teachers develop their practice by reflecting on their behaviour and viewing teaching as 'learning' (Peressini, Borko, Romagnano, Knuth, $\&$ Willis, 2004). Since teachers' behaviours include their instructional practice, we suggest ES can serve as both a theory of teacher professional learning and a theory of instruction (Wayne, Yoon, Zhu, Cronen, \& Garet, 2008). In other words, we suggest that ES can serve as a theory to connect teacher emotional development to their behaviours, including their teaching and learning practices across the teacher learning trajectory.

Moreover, Goldin et al.'s (2011) theory of ES has overarching value, in that it can connect teachers' prior 'in-the-moment' behaviour as mathematics learners with their 'in-the-moment' behaviour as mathematics teachers. We suggest ES can serve as a key area for teacher knowledge development where teachers may link how their "in-the-moment" mathematical affect connects to students' affective domains and mathematical practices. That is, ES can be bidirectional and can serve both students and teachers. Further, raising teacher awareness of their ES and student ES may support development of affective classroom practices, such as managing change. When teachers recognize the mirroring of their affective ES by their students and then respond accordingly, the idea of transcendental ES can aid with teachers' concern for pupils (Fuller, 1969), and may prove a viable framing for culturally responsive teaching (Delpit, 1993; Gay, 2010). This recognition situates ES as an especially powerful intervention measure for students and teachers to co-construct and engage in meaningful learning transactions in a community of practice (Boykin et al., 2011; Darling-Hammond \& Richardson, 2009; Lave \& Wenger, 1991).

Establishing discussions with teachers on identifying and addressing in-themoment' ES of both students and teachers, as part of professional development, may promote affective teacher behaviours with a powerful effect for learning. A 
longer term aim must be to counter the detrimental attributes of negative emotions in school, those that detract from teaching and learning, both now and in the future. This is important for teachers' overall well-being at the personal level, and for what Liu et al. (2008) described as teacher quality at the school organisational level, as affect (such as satisfaction) renews and recommits teachers to schools. This stands in sharp contrast to the new professional "technicist" skills that are frequently promoted in teacher education (Zeichner, 2010). It is now more imperative than ever to examine teachers' affective as well as cognitive abilities to teach mathematics in order to serve all students with a socially just and equitable education.

\section{References}

$\mathrm{Au}, \mathrm{W}$. (2007). High-stakes testing and curricular control: A qualitative meta-synthesis. Educational Researcher, 36(5), 258-267.

Bibby, T. J. (2002). Shame: An emotional response to doing mathematics as an adult and a teacher. British Educational Research Journal, 28(5), 705-721.

Black, L., Mendick, H., \& Solomon, Y. (Eds.). (2009). Mathematical relationships in education. Identities and participation. London, England: Routledge.

Borko, H. (2004). Professional development and teacher learning: Mapping the terrain. Educational Researcher, 33(8), 3-15.

Borko, H., \& Putnam, R. T. (1996). Learning to teach. In D. C. Berliner \& R. C. Calfee (Eds.), Handbook of educational psychology (pp. 673-708). London, England: Prentice Hall.

Boykin, A. W., Noguera, P., \& Ebrary, I. (2011). Creating the opportunity to learn: Moving from research to practice to close the achievement gap. Alexandria, VA: ASCD.

Brown, L., \& Reid, D. (2006). Embodied cognition: Somatic markers, purposes and emotional orientations. Educational Studies in Mathematics, 63(2), 179-192.

Bursal, M., \& Paznokas, L. (2006). Mathematics anxiety and preservice elementary teachers' confidence to teach mathematics and science. School Science and Mathematics, 106(4), 173-180.

Bybee, R. W. (2015). The BSCS 5E instructional model: Creating teachable moments. In: National Science Teachers Association (pp. 1-35). Arlington, VA: NSTA.

Calvo, R. A., \& D'Mello, S. K. (Eds.). (2011). New perspectives on affect and learning technologies (Vol. 3). New York, NY: Springer.

Carmack, S. (2014). Making Sense of Well-being: A Mixed-methods study applying sense-making theory to explore the role of communication competence and social support in physical, emotional, mental and comprehensive well-being (Doctoral dissertation, George Mason University).

Cobb, P. (1994). Where is the mind? Constructivist and sociocultural perspectives on mathematical development. Educational Researcher, 23(7), 13-20.

Cohen, D. K., \& Ball, D. L. (1990). Relations between policy and practice: A commentary. Educational Evaluation and Policy Analysis, 12(3), 331-338.

Collie, R. J., Shapka, J. D., \& Perry, N. E. (2012). School climate and social-emotional learning: Predicting teacher stress, job satisfaction, and teaching efficacy. Journal of Educational Psychology, 104(4), 1189.

Cooper, P. M. (2003). Effective white teachers of black children: Teaching within a community. Journal of Teacher Education, 54(5), 413-427.

Creswell, J. W. (2009). Editorial: Mapping the field of mixed methods research. Journal of Mixed Method Research., 3(2), 95-108.

Csikszentmihalyi, M. (1990). Flow: The psychology of optimal experience. New York, NY: Harper and Row. 
Dalgleish, T., \& Power, M. J. (1999). Handbook of cognition and emotion. Chichester, New York: Wiley.

Damasio, A. R. (2006). Descartes' error: Emotion, reason and the human brain. London, England: Vintage.

Darling-Hammond, L., \& McLaughlin, M. W. (1999). Investing in teaching as a learning profession: policy problems and prospects. In L. Darling-Hammond \& G. Skyes (Eds.), Teaching as the learning profession (pp. 376-412). San Francisco, CA: Jossey-Bass.

Darling-Hammond, L., \& Richardson, N. (2009). Research review/teacher learning: What matters. Educational Leadership, 66(5), 46-53.

DeBellis, V. A., \& Goldin, G. A. (1997). The affective domain in mathematical problem solving. In E. Pehkonen (Ed.), Proceedings of the 21st Conference of the International Group for the Psychology of Mathematics Education (Vol. 2, pp. 209-216). Lahti, Finland: PME.

DeBellis, V. A., \& Goldin, G. A. (2006). Affect and meta-affect in mathematical problem solving: A representational perspective. Educational Studies in Mathematics, 63(2), 131-147.

Delpit, L. (1993). The politics of teaching literate discourse. In Freedom's plough: Teaching in the multicultural classroom (pp. 285-295).

Delpit, L. (1995). Other people's children: Cultural conflict in the curriculum. New York, NY: New York Press.

Desimone, L. M. (2009). Improving impact studies of teachers' professional development: Toward better conceptualizations and measures. Educational Researcher, 38(3), 181-199. https://doi.org/ 10.3102/0013189x08331140.

Dieker, L., Hynes, M., Hughes, C., \& Smith, E. (2008). Implications of mixed reality and simulation technologies on special education and teacher preparation. Focus on Exceptional Children, 40(6), $1-20$.

Dieker, L., Rodriguez, J., Lignugaris-Kraft, B., Hynes, M., \& Hughes, C. (2014). The future of simulated environments in teacher education. Teacher Education and Special Education, 37(1), $21-33$.

Drodge, E. N., \& Reid, D. A. (2000). Embodied cognition and the mathematical emotional orientation. Mathematical Thinking and Learning, 2(4), 249-267.

Enicks, A., Whitten, E., Morgan, D., \& Dieker, L. (2013). Findings on the use of TeachLIVE®, a mixed-reality teaching environment, to prepare special educators. In Association of Teacher Educators Annual Meeting. Atlanta, GA: ATE.

Fenton-O'Creevy, M., Soane, E., Nicholson, N., \& Willman, P. (2011). Thinking, feeling and deciding: The influence of emotions on the decision making and performance of traders. Journal of Organizational Behavior, 32(8), 1044-1061.

Fisher, M. H., \& Royster, D. (2016). Mathematics teachers' support and retention: Using Maslow's hierarchy to understand teachers' needs. International Journal of Mathematical Education in Science and Technology, 1-16.

Flores, A., Park, J., \& Bernhardt, S. A. (2016). Learning mathematics and technology through inquiry, cooperation, and communication: A learning trajectory for future. In M. Niess, S. Driskill, $\&$ K. Hollebrands (Eds.), Handbook of research on transforming mathematics teacher education in the digital age (p. 324). IGI Global: Hershey, PA.

Frey, A., \& Doyle, H. D. (2001). Classroom meetings: A program model. Children and Schools, 23(4), 212-222.

Freire, P. (2005). Teachers as cultural workers: Letters to those who dare teach with new commentary by Peter McLaren, Joe L. Kincheloe, and Shirley Steinberg Expanded Edition. Boulder, CO: Westview.

Fuller, F. F. (1969). Concerns of teachers: A developmental conceptualization. American Educational Research Journal, 6(2), 207-226.

Gay, G. (2010). Culturally responsive teaching: Theory, research, and practice. New York, NY: Teachers College.

Gee, J. P. (2002). Identity as an analytic lens for research in education. Review of Research in Education, 25, 99-125. 
Gerring, J. (2017). Case study research: Principles and practices. New York: Cambridge University Press.

Goldin, G. A. (1998). Representational systems, learning, and problem solving in mathematics. The Journal of Mathematical Behavior, 17(2), 137-165.

Goldin, G. A. (2000). Affective pathways and representation in mathematical problem solving. Mathematical Thinking and Learning, 2(3), 209-219.

Goldin, G. A. (2014). Perspectives on emotion in mathematical engagement, learning, and problem solving. In R. Pekrun \& L. Linnenbrink-Garcia (Eds.), International handbook of emotions in education (pp. 391-414). New York, NY: Routledge.

Goldin, G. A. (2015). Motivating desires for classroom engagement in the learning of mathematics. In Proceedings of the 21 st International Conference on Mathematical Views (MAVI). Milan, Italy: Polytechnic University of Milan.

Goldin, G. A., Epstein, Y. M., \& Schorr, R. Y. (2007). Affective pathways and structures in urban students' mathematics learning. In D. K. Pugalee, A. Rogerson, \& A. Schinck (Eds.), Mathematics Education in a Global Community: Proceedings of the 9th International Conference of the Mathematics Education into the 21st Century Project (pp. 260-265). Beijieng, China: ICME.

Goldin, G. A., Rösken, B., \& Törner, G. (2009). Beliefs - No longer a hidden variable in mathematics teaching and learning processes. In J. Maass, \& W. Schlöglmann (Eds.), Beliefs and attitudes in mathematics education: New research results (pp. 1-18). Rotterdam: Sense Publishers.

Goldin, G. A., Epstein, Y. M., Schorr, R. Y., \& Warner, L. B. (2011). Beliefs and engagement structures: Behind the affective dimension of mathematical learning. ZDM Mathematics Education, 43, 547-556.

Goldin, G. A., Hannula, M. S., Heyd-Metzuyanim, E., Jansen, A., Kaasila, R., Lutovac, S., et al. (2016). Attitudes, beliefs, motivation, and identity in mathematics education. An overview of the field and future directions. In Springer open (pp. 1-35). New York, NY: Springer.

Greeno, J. G., Collins, A. M., \& Resnick, L. B. (1996). Cognition and learning. In D. Berliner \& R. Calfee (Eds.), Handbook of educational psychology (Vol. 77, pp. 15-46).

Gregory, A., \& Weinstein, R. S. (2008). The discipline gap and African Americans: Defiance or cooperation in the high school classroom. Journal of School Psychology, 46(4), 455-475.

Haberman, M. (2005). Teacher burnout in black and white. New Educator, 1, 153-175.

Hagenauer, G., Hascher, T., \& Volet, S. E. (2015). Teacher emotions in the classroom: Associations with students' engagement, classroom discipline and the interpersonal teacher-student relationship. European Journal of Psychology of Education, 30(4), 385-403.

Hill, H., \& Ball, D. L. (2009). The curious and crucial case of mathematical knowledge and teaching. Phi Delta Kappan, 91(2), 68-71.

Hollingsworth, S. (1989). Prior beliefs and cognitive change in learning to teach. American Educational Research Journal, 26, 160-189.

Horn, I. S., Nolen, S. B., Ward, C., \& Campbell, S. S. (2008). Developing practices in multiple worlds: The role of identity in learning to teach. Teacher Education Quarterly, 35(3), 61-72.

Howard, T. C. (2001). Telling their side of the story: African-American students' perceptions of culturally relevant teaching. The Urban Review, 33(2), 131-149.

Ingersoll, R. M., \& Perda, D. (2010). Is the supply of mathematics and science teachers sufficient? American Educational Research Journal, 47(3), 563-594.

Kelly, P. (2006). What is teacher learning? A socio-cultural perspective. Oxford Review of Education, 32(4), 505-519.

Khalil, D., \& Hughes, G., (2016). Paradox or process? A description of novice teachers' powerful mathematical affect and their instructional performance in Teachlive ${ }^{\mathrm{TM}}$ Rehearsals. In C. Csikos, A. Rausch, \& J. Szitanyi (Eds). Proceedings of the 40th Conference of the International Group for the Psychology of Mathematics Education (Vol. 3, pp. 83-90). Szged, Hungary: PME.

Khalil, D., Hughes, G., Gosselin, C., \& Edwards, L. (2016). TeachLive ${ }^{\mathrm{TM}}$ rehearsals: One HBCU's study on prospective teachers' reformed instructional practices and their mathematical affect. In M. Wood, E. Turner, \& M. Civil (Eds.), Proceedings of the 38th Annual Meeting of the North 
American Chapter of the International Group for the Psychology of Mathematics Education. Tucson, AZ: University of Arizona.

Kleinfeld, J. (1975). Effective teachers of Eskimo and Indian students. The School Review, 83(2), 301-344.

Kyriacou, C. (2001). Teacher stress: Directions for future research. Educational Review, 53(1), $27-35$.

Korthagen, F. (2016). Inconvenient truths about teacher learning: Towards professional development 3.0. Teachers and Teaching, 1-19.

Krzywacki, H., \& Hannula, M. S. (2010). Tension between present and ideal state of teacher identity in the core of professional development. In M. M. F. Pinto \& T. F. Kawasaki (Eds.), Proceedings of the 34th Conference for the International Group for the Psychology of Mathematics Education(Vol. 1, pp. 267-271). Belo Horizonte, Brazil: PME.

Lake, E., \& Nardi, E. (2014). Looking for Goldin: Can adopting student engagement structures reveal engagement structures for teachers? The case of Adam. In C. Nicol, S. Oesterle, P. Liljedahl, \& D. Allan (Eds.), Proceedings of the 38th Conference of the International Group for the Psychology of Mathematics Education. Vancouver, BC: PME.

Lave, J., \& Wenger, E. (1991). Situated learning: Legitimate peripheral participation. Cambridge, UK: Cambridge University Press.

Lazarus, R. S. (1991). Emotion and adaptation. New York, NY: Oxford University Press.

Lee, H. J., \& Boyadzhiev, I. (2013). Challenging common misconceptions of fractions through GeoGebra. In R. McBride \& M. Searson (Eds.), Proceedings of Society for Information Technology and Teacher Education International Conference. Chesapeake, VA: AACE.

Lewis, G. (2013). Emotion and disaffection with school mathematics. Research in Mathematics Education, 15(1), 70-86.

Liljedahl, P. G. (2005). Mathematical discovery and affect: The effect of AHA! experiences on undergraduate mathematics students. International Journal of Mathematical Education in Science and Technology, 36(2-3), 219-234.

Liu, E., Rosenstein, J. G., Swan, A. E., \& Khalil, D. (2008). When districts encounter teacher shortages: The challenges of recruiting and retaining mathematics teachers in urban districts. Leadership and Policy in Schools, 7(3), 296-323.

Mansfield, C. F., \& Volet, S. E. (2010). Developing beliefs about classroom motivation: Journeys of preservice teachers. Teaching and Teacher Education, 26(7), 1404-1415. https://doi.org/10. 1016/j.tate.2010.04.005.

McLeod, D. B. (1994). Research on affect and mathematics learning in the JRME: 1970 to the Present. Journal for Research in Mathematics Education, 25(6), 637-647.

Meyer, D. K., \& Turner, J. C. (2006). Re-conceptualizing emotion and motivation to learn in classroom contexts. Educational Psychology Review, 18(4), 377-390. https://doi.org/10.1007/ s10648-006-9032-1.

Miles, M. B., \& Huberman, A. M. (1994). Qualitative data analysis: A sourcebook. Beverly Hills, CA: Sage.

Milner, H. R., Flowers, L. A., Moore, E., Moore, J. L., \& Flowers, T. A. (2003). Preservice teachers' awareness of multiculturalism and diversity. The High School Journal, 87(1), 63-70.

Monroe, C. R. (2005). Understanding the discipline gap through a cultural lens: Implications for the education of African American students. Intercultural Education, 16(4), 317-330.

Moore, F. (2008). Agency, identity, and social justice education: Preservice teachers' thoughts on becoming agents of change in urban elementary science classrooms. Research in Science Education, 38, 589-610.

Mottet, T. P., \& Beebe, S. A. (2002). Relationships between teacher nonverbal immediacy, student emotional response, and perceived student learning. Communication Research Reports, 19(1), $77-88$.

Nieto, S. (2003). What keeps teachers going? New York: Teachers College Press. 
Parker, P. D., Martin, A. J., Colmar, S., \& Liem, G. A. (2012). Teachers' workplace well-being: Exploring a process model of goal orientation, coping behavior, engagement, and burnout. Teaching and Teacher Education, 28(4), 503-513.

Patrick, H., Ryan, A. M., \& Kaplan, A. (2007). Early adolescents' perceptions of the classroom social environment, motivational beliefs, and engagement. Journal of Educational Psychology, 99(1), 83.

Peressini, D., Borko, H., Romagnano, L., Knuth, E., \& Willis, C. (2004). A conceptual framework for learning to teach secondary mathematics: A situative perspective. Educational Studies in Mathematics, 56(1), 67-96.

Planke, S. B., \& Condliffe, B. F. (2013). Pressures of the season: An examination of classroom quality and high-stakes accountability. American Educational Research Journal, 50, 1152-1182.

Puchner, L. D., \& Taylor, A. R. (2006). Lesson study, collaboration and teacher efficacy: Stories from two school-based math lesson study groups. Teaching and teacher education, 22(7), 922-934.

Ronfeldt, M. (2012). Where should student teachers learn to teach? Effects of field placement school characteristics on teacher retention. Educational Evaluation and Policy Analysis, 34(1), 3-26.

Schlöglmann, W. (2006). Meta-affect and strategies in mathematics learning. In M. Bosch (Ed.), Proceedings of the Fourth Congress of the European Society for Research in Mathematics Education (pp. 275-285). Barcelona: Universitat Ramon Llul, IQS.

Schorr, R. Y., \& Goldin, G. A. (2008). Students' expression of affect in an inner-city simcalc classroom. Educational Studies in Mathematics, 68(2), 131-148.

Schorr, R. Y., Epstein, Y. M., Warner, L. B., \& Arias, C. C. (2010). Mathematical truth and social consequences: The intersection of affect and cognition in a middle school classroom. Mediterranean Journal for Research in Mathematics Education, 9(1),107-134.

Schutz, P., Hong, J., Cross, D., \& Osbon, J. (2006). Reflections on investigating emotion in educational activity settings. Educational Psychology Review, 18(4), 343-360.

Spillane, J. P., Halverson, R., \& Diamond, J. B. (2004). Towards a theory of leadership practice: A distributed perspective. Journal of Curriculum Studies, 36(1), 3-34. https://doi.org/10.1080/ 0022027032000106726.

Titsworth, S., McKenna, T. P., Mazer, J. P., \& Quinlan, M. M. (2013). The bright side of emotion in the classroom: Do teachers' behaviors predict students' enjoyment, hope, and pride? Соттиnication Education, 62(2), 191-209.

Verner, I., Massarwe, K., \& Bshouty, D. (2013). Constructs of engagement emerging in an ethnomathematically-based teacher education course. The Journal of Mathematical Behavior, 32(3), 494-507.

Ware, F. (2006). Warm demander pedagogy: Culturally responsive teaching that supports a culture of achievement for African American students. Urban Education, 41(4), 427-456.

Wayne, A. J., Yoon, K. S., Zhu, P., Cronen, S., \& Garet, M. S. (2008). Experimenting with teacher professional development: Motives and methods. Educational Researcher, 37(8), 469-479.

Weber, K. (2008). The role of affect in learning real analysis: A case study. Research in Mathematics Education, 10(1), 71-85.

Zeichner, K. (2010). Competition, economic rationalization, increased surveillance, and attacks on diversity: Neo-liberalism and the transformation of teacher education in the US. Teaching and Teacher Education, 26(8), 1544-1552.

Zeichner, K. M., \& Gore, J. M. (1990). Teacher socialization. In W. R. Houston (Ed.), Handbook of research on teacher education (pp. 329-348). New York, NY: Macmillan.

Zeldin, A. L., \& Pajares, F. (2000). Against the odds: Self-efficacy beliefs of women in mathematical, scientific, and technological careers. American Educational Research Journal, 37(1), 215-246. 
Open Access This chapter is licensed under the terms of the Creative Commons Attribution 4.0 International License (http://creativecommons.org/licenses/by/4.0/), which permits use, sharing, adaptation, distribution and reproduction in any medium or format, as long as you give appropriate credit to the original author(s) and the source, provide a link to the Creative Commons license and indicate if changes were made.

The images or other third party material in this chapter are included in the chapter's Creative Commons license, unless indicated otherwise in a credit line to the material. If material is not included in the chapter's Creative Commons license and your intended use is not permitted by statutory regulation or exceeds the permitted use, you will need to obtain permission directly from the copyright holder.

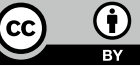

